\title{
Component Trade and China's Global Economic Integration
}

\author{
Kunwang Li, ${ }^{1}$ Ligang Song, ${ }^{2}$ \\ and Xingjun Zhao ${ }^{3}$
}

November 2008

\begin{abstract}
China's engagement in the so-called international fragmentation of production - namely 'cross-border dispersion of component production/assembly within vertically integrated manufacturing industries' - has become an increasingly important form of its economic integration into the regional as well as the global economy. The paper presents the recent trend of trade in parts and components between China and its main trading partners. Applying an adjusted gravity modelling method, the paper explores how China's pattern of trade in parts and components is being determined. The paper found that China's rapid economic growth, increasing market size and economies of scale, foreign direct investment and infrastructure development including transportation and telecommunications are important factors in explaining China's rapid increase of bilateral trade in parts and components with its trading partners. The paper also found that the spatial distance and transportation costs have significant negative impacts on China's trade of parts and components suggesting that the reduction in transportation costs by technological innovation and investment could enhance trade in parts and components, and thereby deepen the process of international specialization involving China and its main trading partners. The paper argues that given the prospects of the rapid growth of the Chinese economy, its current and planned massive investments in R\&D and in infrastructure, its continual policies in attracting FDI and its rapid move towards liberalizing its services sectors including its financial sectors, the scope for China and its trading partners to benefit from the process of international fragmentation of production is tremendous.
\end{abstract}

Keywords: component trade, international fragmentation of production, gravity model

JEL classification: F11, F14, F15

\section{Copyright (C) UNU-WIDER 2008}

1 Nankai University, China, e-mail: likunwang@nankai.edu.cn; 2 Australian National University, Australia, e-mail: ligang.song@anu.edu.au; 3 Sino Steel Industry and Trade Corporation.

This study has been prepared within the UNU-WIDER project on Southern Engines of Global Growth, co-directed by Amelia U. Santos-Paulino and Guanghua Wan.

UNU-WIDER gratefully acknowledges the financial contributions to the research programme by the governments of Denmark (Royal Ministry of Foreign Affairs), Finland (Ministry for Foreign Affairs), Norway (Royal Ministry of Foreign Affairs), Sweden (Swedish International Development Cooperation Agency_Sida) and the United Kingdom (Department for International Development). 


\section{Acknowledgements}

The paper was prepared, based on an updated version of a chapter in China: Linking Markets for Growth, by Ross Garnaut and Ligang Song (eds) (Asia Pacific Press 2007), for the UNU-WIDER conference on Southern Engines of Growth: China, India, Brazil and South Africa in Helsinki on 7-8 September 2007.

Tables and figures appear at the end of the paper.

The World Institute for Development Economics Research (WIDER) was established by the United Nations University (UNU) as its first research and training centre and started work in Helsinki, Finland in 1985. The Institute undertakes applied research and policy analysis on structural changes affecting the developing and transitional economies, provides a forum for the advocacy of policies leading to robust, equitable and environmentally sustainable growth, and promotes capacity strengthening and training in the field of economic and social policy making. Work is carried out by staff researchers and visiting scholars in Helsinki and through networks of collaborating scholars and institutions around the world.

www.wider.unu.edu publications@wider.unu.edu

UNU World Institute for Development Economics Research (UNU-WIDER)

Katajanokanlaituri 6 B, 00160 Helsinki, Finland

Typescript prepared by Janis Vehmaan-Kreula at UNU-WIDER

The views expressed in this publication are those of the author(s). Publication does not imply endorsement by the Institute or the United Nations University, nor by the programme/project sponsors, of any of the views expressed. 


\section{Introduction}

A symbol of China's economic integration into the global economy is its progressive engagement in international commodity trade, with an increasing scale and intensity. From 1992 to 2005, the average growth rate of China's total trade was 18.5 per cent per annum - twice as high as the growth of gross domestic product (GDP) in the same period. China's total trade reached US\$1.76 trillion in 2006, with a trade dependency ratio (defined as the ratio of total trade over its GDP) rising to about 68 per cent by the national account measures (UNCTAD 2006). Among this increasing trade, China's engagement in the so-called international fragmentation of production - namely, 'crossborder dispersion of component production/assembly within vertically integrated manufacturing industries' (Feenstra 1998; Jones and Kierzkowski 2005) - has become an increasingly important form of its economic integration into the regional as well as the global economy.

The development of component trade is significant for the following reasons (Jones et al. 2005). First, it has exhibited a dynamism exceeding that of trade in final goods, as breaking down the integrated process into separate stages of production opens up new possibilities for exploiting gains from specialization (Jones and Kierzkowski 2001). Second, despite it being a type of trade increasingly paramount in advanced stages of globalization, it opens up an important role for developing economies (unlike intraindustry trade, which has been conducted mainly among industrialized countries). Third, it is more closely related to the development and liberalization of the services sector than final good trade is particularly with respect to transportation, communication, banking and insurance, and other connecting service links. This is because increasing returns to scales tend to be associated with the development of these service sectors, which could in turn reduce the costs associated with the fragmentation process.

The global total trade in parts and components increased from US\$400 billion in 1992 to US\$1.25 trillion in 2005. The share of component trade in the total trade of manufacturing goods increased from 21 per cent to 26 per cent. Such a trend is especially pronounced in the East Asian region, which has accounted for more than half of the trade in parts and components. East Asia is progressively replacing the United States and the European Union as the world's largest region for trade in parts and components, forming a large integrated network for production (Athukorala 2006). China has been playing an increasingly important role in this development.

This paper presents the recent trend of trade in parts and components between China and its main trading partners. It explores how China's pattern of trade in parts and components is being determined in terms of the shares of this trade in its total exports and imports, and their respective shares in total manufacturing trade. The analytical approach adopted is an adjusted gravity modelling method incorporating relative labour costs, foreign direct investment (FDI) and telecommunications in estimating the regression models. Policy implications with respect to the role of technology, labour productivity, further development and liberalization of the services sectors are then discussed. 
The rise of China's trade has been an important part of the changing pattern of international production segmentation in East Asia. On the import side, the share of parts and components had already accounted for more than one-third of the total imports in China in 2002. Among the intermediate goods trade, imports of parts and components increased more significantly than any other intermediate goods and the share of parts and components in total imports increased from 19 per cent in 1997 to 27 per cent in 2002. On the exportation side, final goods played a dominant part in total exports accounting for more than 60 per cent of the total in 2002. Meanwhile, China's intermediate goods trade has been concentrated mainly in Asia: more than 80 per cent comes from Asia and more than 60 per cent of exports of parts and components goes to other Asian economies (Gaulier et al. 2005). In general, importing intermediate goods, then processing and exporting the final goods characterizes China's trading relations with its main trading partners.

To analyse China's trade in parts and components with its main trading partners, we select 219 kinds of parts and components taken from the United Nations' Standard International Trade Classification (SITC Version 3) numbers SITC-7 and SITC-8, consisting of 2,800 commodities, following Yeats (2001) and Athukorala (2006). 1 Altogether, there are 25 trading partners: the United States, Canada, Mexico, the United Kingdom, France, Germany, Italy, Australia, Japan, Korea, Hong Kong, Singapore, Malaysia, the Philippines, Thailand, Indonesia, Vietnam, Myanmar, Cambodia, Brunei, Laos, India, Brazil, Pakistan and South Africa. ${ }^{2}$

Since the early 1990s, trade in parts and components between China and its trading partners has been increasing rapidly. In 1992, China's imports and exports of parts and components were worth US\$12.1 billion and US\$4.3 billion respectively (Figures 1 and 2). By 2005, China's imports and exports of parts and components increased to US\$176 billion and US\$110 billion - 15 times and 26 times those in 1992 respectively (Figure 1). Growth of imports of parts and components is continuing to outpace that of exports.

At the same time, the share of imports of parts and components in total manufacturing imports increased dramatically from 16 per cent in 1992 to 35 per cent in 2005 (Figure 2). The fact that component trade accounted for more than one-third of total manufacturing imports illustrates China's increasing role in international fragmentation of production.

To further analyse the increasing trend of trade in parts and components, one needs to look at the distribution of component trade by sector as well as by destination. The former tells how component trade concentrates on certain sectors and the latter shows with whom China has engaged in developing component trade.

1 SITC Version 3 was adopted in 1992 so the data series used in this paper began in that year.

2 In selecting partnering countries, consideration includes country representation and availability of data. 


\section{The pattern of component trade by sectors}

In 1992, China's exports of parts and components for machinery and transportation (SITC-7) were worth US\$3.4 billion, which accounted for 80 per cent of the total exports of parts and components and 5.1 per cent of manufacturing exports (Table 1). In the same year, its exports of parts and components for other manufacturing goods were worth US\$800 million, accounting for 19 per cent of total exports of parts and components and 1.2 per cent of manufacturing exports. Exports of parts and components accounted for 6.3 per cent of total manufacturing exports.

In 2004, China's exports of parts and components for machinery and transportation were worth US\$87.5 billion, accounting for 94 per cent of the total exports of parts and components and 15.9 per cent of total manufacturing exports. Its exports of parts and components for other manufacturing goods were worth US\$5.5 billion, accounting for 5.8 per cent of the total exports of parts and components and 1 per cent of manufacturing exports. Total exports of parts and components accounted for 16.9 per cent of total manufacturing exports. The annual growth rate of exports of parts and components for machinery and transport in this period was 31 per cent, while that of other manufacturing was 17.1 per cent. The annual growth rate of total exports of parts and components was 29.3 per cent.

China's imports of parts and components for machinery and transportation were worth US $\$ 10$ billion in 1992, accounting for 87 per cent of total imports of parts and components and 15.8 per cent of total manufacturing imports (Table 1). China's imports of parts and components for other manufacturing goods were worth US\$1.6 billion, accounting for 13 per cent of total imports of parts and components and 2.4 per cent of total manufacturing imports in the same year. Total imports of parts and components accounted for 18.2 per cent of total imports of manufactured products.

In 2004, China's imports of parts and components for machinery and transportation increased to US\$148 billion, accounting for 97 per cent of total imports of parts and components and 33.4 per cent of total manufacturing imports. China's imports of other parts and components climbed to US\$4.1 billion, accounting for 2.7 per cent of total imports of parts and components and 1 per cent of total manufacturing imports. Total imports of parts and components accounted for 34.3 per cent of manufacturing product imports. The annual growth rate of imports of machinery and transportation products was, on average, 24.7 per cent and that of imports in other parts and components was 8.2 per cent in this period. The annual growth rate of total imports in parts and components was 23.4 per cent, on average, in this period.

Machinery and transportation products increased more quickly than other products in component trade. In particular, office machinery and equipment (SITC-75), telecommunications and recording equipment (SITC-76) and electrical machinery and parts (SITC-77) played dominant roles, accounting for nearly 80 per cent of the total component trade. As a result, the share of machinery and transportation in the total trade of parts and components is increasing while that of other manufacturing products is decreasing over time. This finding is consistent with the fact that the composition of China's exports has been moving quickly towards those capital and technologyintensive products in recent years. 
China has been running component-trade deficits, caused mainly by rapid increases in its importation of parts and components for machinery and transportation products. This trade gap tends to increase further as China's capacity for producing these products increases, so China will continue to rely heavily on imported parts and components. On the other hand, China has become a net exporter of parts and components relating to labour-intensive manufacturing products since 2000.

The growth rates of China's component trade have been higher than the growth rates of manufacturing sectors as well as the growth rates of total trade. This suggests that the pattern of the international division of labour in which China has participated has been deepened to cover finer international fragmentation of production. The further development of such patterns means that countries involved will gain from trade in parts and components rather than from trade in final goods. Such development will cement even closer trading relationships among countries involved in such a network of production. This point can be illustrated by looking at China's trade in parts and components by partners.

\section{$4 \quad$ China's trade in parts and components by partners}

Although the regional distribution of China's imports of parts and components varies over time, the main sources of China's imports of parts and components seem to concentrate in Northeast Asia, which accounted for more than 50 per cent of China's total imports of components (Table 2). Japan's share was increasing between 1992 and 1997, but started to fall after 1998, due possibly to the impact of the East Asian financial crisis. Japan, however, together with Korea (whose share increased rapidly throughout the period), ranked the highest in terms of their shares of China's imports of components. The shares of the United States and Canada reached their peak about 2000 and started to decline thereafter. Hong Kong's share decreased from 38.7 per cent to 2.15 per cent, reflecting the fact that it was no longer a major supplier of parts and components to China. The shares from four EU countries (Germany, France, the United Kingdom and Italy) also decreased to low levels in 2005. Imports of parts and components from five Association of South-East Asian Nations (ASEAN) countries (Malaysia, the Philippines, Indonesia, Singapore and Thailand) increased rapidly from less than 1 per cent in 1992 to 18 per cent in 2005.

The data show that China has been relying less and less on the major industrialized countries in Europe and North America to provide parts and components for its part in the international fragmentation of production. In contrast, the newly industrialized economies and ASEAN countries have become important sources of China's imports of parts and components. There is also a strong tendency for Korea and large ASEAN countries to replace Japan and Hong Kong in providing China with parts and components. The rapid development of component trade between China and its neighbouring economies in East and Southeast Asia indicates that these regional economies have become increasingly integrated through the international fragmentation of production.

Total exports of parts and components from China to industrialized countries have been increasing steadily, while those to East Asia - in particular, to Hong Kong and Japan have been falling (Table 3). Despite this trend, East Asia's average share of China's exports to the world was about 55 per cent compared with 17 per cent for the North 
American Free Trade Agreement (NAFTA) countries and 7 per cent for the European Union in 2005. Exports to Korea have increased from 1.3 per cent to 5 per cent and those to six ASEAN countries (Singapore, Philippines, Indonesia, Malaysia, Thailand and Vietnam) have also increased - from 4.1 per cent in 1992 to 12 per cent in 2005.

Korea, Japan and the six ASEAN countries have become important sources of China's imports of parts and components, accounting for more than 50 per cent of China's total imports of these products (Table 3). As those of Japan and Hong Kong are decreasing, the shares of Korea and ASEAN countries have been increasing. This implies that there have been some substitution effects between Japan, Hong Kong and other Asian countries in providing parts and components to China. Despite this substitution effect, China's continuing strong demand for parts and components from the region will be conducive to the economic growth of regional economies.

About 55 per cent of China's exports of parts and components have been to Northeast and Southeast Asia, with China's major exporting markets being Hong Kong, Japan, Korea, Singapore, Malaysia and Thailand. This trend is likely to be strengthened further. At the same time, China's export shares to North America and Europe have been steadily increasing over time. Overall, China's relatively high export and import shares of parts and components to East Asia supports the view that China has engaged more deeply with East Asian economies in forging this new type of international specialization in production. China's export shares of parts and components to Australia have been generally higher than its import shares, but both shares have been relatively low compared with East Asian economies.

\section{Determinants of China's component trade}

In explaining the phenomenon of component trade or international fragmentation of production, Jones (2007) postulates the following theories. The first is a Ricardian one, which says that workers have different skills across different areas of a country, and when the skills required in each production block (fragments) differ, then a dispersion of activity according to comparative advantage could lower marginal production costs. The second theory is a Heckscher-Ohlin type of difference, namely the production blocks differ from each other in the proportions of different factors that are required. This suggests that labour-intensive production blocks would better be located in regions in which labour is relatively inexpensive compared with productivity.

The third theory is that fragmentation introduces new costs, namely the costs of connecting the two or more production blocks by service links such as transportation and communication. Therefore, 'the movement towards deregulation, especially of services, and the technological changes that have drastically reduced the costs of communication as well as making transportation less expensive have all encouraged a fragmentation of previously vertically integrated production processes' (Jones and Marjit 2001: 365). Furthermore, it is argued that the optimal degree of fragmentation depends on the size of the market, so economic growth in general encourages fragmentation and trade in parts and components (Jones et al. 2005). We examine in this section the main determinants of China's trade in parts and components based on these theories. 
The theory of comparative advantage has been consistent with China's trading pattern: China produces and exports a large range of mainly labour-intensive goods, such as textiles and clothing, shoes, toys, travel goods and furniture.

The question is whether the theory of comparative advantage can be applied also in analysing intra-product trade based on vertical specialization of production such as component trade. China tends to focus on producing parts and components relating to labour-intensive products due to its abundant supply of labour. For example, the production of personal computers requires a lot of components, including central processing units, mainboards, sound cards, display cards, screens and so on. Although China has no comparative advantage in producing some of the key components, it can assemble and export a large quantity of personal computers since it has low-cost production for the assembly of those components.

One way to examine the relationship between comparative advantage and the production and trade of parts and components is to compare labour-cost differences across different countries. Wages are a good index as they reflect the supply and demand of the labour market as well as the quality of labour. When a country's wage levels are relatively low, it could indicate that the country has comparative advantage in producing labour-intensive products, including parts and components.

In the period 1992-2004, labour costs in China were far lower than those in most industrialized countries, including the United States, Japan, Canada, Germany and the United Kingdom (Table 4). They were also relatively lower than many developing economies in Asia such as Korea, Hong Kong, Singapore, Malaysia and Thailand.

With respect to the impact of economy of scale on component trade, it is usually the case that rapid economic growth requires a large market to accommodate the products being produced. The process of trade liberalization in the past few decades - enhanced through multilateral, bilateral or unilateral means - provides China with an external environment in which rising trade from China has been accommodated rather smoothly. The enlarged markets for products made in China have created an enormous economy of scale in production. It is known that the degree of specialization of production tends to be intensified when there are economies of scale in production. As economy of scale is enlarged, the production and trade of parts and components within and across different countries tend to be enhanced.

On the other hand, China has a large domestic market, implying that there is a relative thickness in the market in those competitive sectors (meaning that there are relatively more suppliers of intermediate goods for a given sector). This is especially true in those sectors such as textiles and clothing, shoes, computers and automobiles. As Grossman and Helpman (2003) note, this characteristic reduces the search costs for multinational companies investing in overseas markets. At the same time, continuing domestic reforms in China provided an improved legal and regulatory environment in which foreign investments have flourished, deepening the process of international specialization in production.

China's transportation and telecommunications industries have experienced rapid growth since the 1990s, providing the necessary infrastructure for China's participation in international specialization. Figures 3 and 4 show the recent development of China's transportation industry. The number of civil aviation airline routes increased from 287 
in 1986 to 1,257 in 2005 - increasing by 3.4 times - and international airline routes also increased, from $108,000 \mathrm{~km}$ to $856,000 \mathrm{~km}$. The capacity of seaports also increased from 300 million tonnes in 1985 to 2.9 billion tonnes in 2005.

China's telecommunications industry has developed rapidly. The number of fixed lines per 1,000 people increased from less than 10, on average, in 1992 to 241 in 2004 (Figure 5). Along with the development of the telecommunications industry, call fees are declining. For example, in 1997, the average cost of calling the United States was US\$6.70, but this reduced to US\$2.90 in 2004. Meanwhile, the number of mobile phones in China has reached 480 million by March 2007 - making it the largest mobilephone market in the world - and the number of people accessing the internet reached 144 million by March 2007, making China the second largest internet-using country after the United States. 3 These facts suggest that the rapid development of China's transportation and telecommunication industries could be another factor influencing the pace and depth of China's participation in international fragmentation of production. This is mainly because the developments in these service links tend to reduce the costs of transactions with considerable benefits from the economies of scale associated with such developments.

FDI has been considered an important determinant of trade in parts and components in the literature because multinational corporations are an important channel for conducting trade in intermediate goods through intra-firm trade. Multinational firms can choose to invest in host countries and make use of the local comparative advantage to produce their intermediate goods. For example, Kaminski and Smarzynska (2001) studied the impact of FDI on Poland's internationalization process and found that the large FDI inflow helped Poland access international specialization and increased the country's trade. Cheng et al. (2001) studied the relationship between FDI and international specialization by using a partial equilibrium model to examine trade between Hong Kong and Guangdong Province, incorporating FDI. They found that FDI was an important factor for production specialization and trade in parts and components in China.

China has absorbed a large amount of FDI since the 1990s and has now become the leading country in the world for the receipt of FDI inflows (Figure 6). The rapid increase of FDI inflows into China promotes the development of processing trades (Spencer 2005). The share of the FDI-related manufacturing sector in the total manufacturing sector has been increasing rapidly, and the share of total processing trade increased from 35 per cent in 1988 to 57 per cent in 2003, surpassing the share of ordinary trade.

Based on the theories surveyed and the background information, we adopted an adjusted gravity model to examine the determinants of trade in parts and components between China and its trading partners. The basic formula is introduced by Egger and Egger (2005) as follows:

3 See 'Internet in the People's Republic of China' on Wikipedia (available online at http://www.wikipedia.com). 


$$
\begin{aligned}
\operatorname{LnPC}_{j . \text { China.t }}= & C_{0}+\alpha_{1} \operatorname{LnAGDP}_{j . \text { China.t }}+\alpha_{2} \operatorname{LnDIST}_{j . \text { China.t }} \\
& +\alpha_{3} \operatorname{LnRWAGE}_{j . \text { China.t }}+\alpha_{4} \operatorname{LnFDI}_{j \text {.China.t }}+\text { LnTeleline }_{j . \text { China.t }}
\end{aligned}
$$

where $P C$ represents either the exportation or importation of parts and components between China and its trading partners, AGDP is the average real GDP of China and its trading partners, DIST is the economic distance between China and its trading partners, RWAGE is the relative labour cost of China and its trading partners, FDI is the foreign direct investment, and Teleline is the average number of fixed telephones in China and its trading partners.

According to Jones and Kierzkowski (2005), these factors can affect the trade in parts and components as well as the final goods. Thus, Equation 1 can be revised as follows:

$$
\begin{aligned}
\text { LnSPC }_{j . \text { China.t }} & =C_{0}+\alpha_{1} \operatorname{LnAGDP}_{j . \text { China.t }}+\alpha_{2} \text { LnDIST }_{j . \text { China.t }} \\
& +\alpha_{3} \operatorname{LnRWAGE}_{j . \text { China.t }}+\alpha_{4} \text { LnFDI }_{j . \text { china.t }}+\text { LnTeleline }_{\text {j.China.t }}
\end{aligned}
$$

where $S P C$ is the share of exports of parts and components in the total trade in manufactured products. A fixed effect is introduced in both equations while conducting the panel data regressions.

The variables used in the regressions are defined as follows: to capture the impact of economy of scale, we use the average GDP of China and its trading partners.

$$
A G D P_{j . \text { China }}=\frac{G D P_{j}+G D P_{\text {China }}}{2}
$$

For the distance variable, we use the weighted-average economic distance to represent the transportation costs in which $\mathrm{DIST}_{f}$ is the physical distance between countries.

$$
D I S T_{\text {China.f }}=\frac{D I S T_{f} * G D P_{f}}{\sum_{f=1}^{20} G D P_{f}}
$$

To reflect the impact of comparative advantage, we use the relative wage (RWAGE) to represent the unit costs of China and its trading partners.

$$
R W A G E_{j . \text { China }}=\frac{\text { Average cost of unit labour per hour }}{\mathrm{j}}
$$

In order to examine the impact of FDI on trade in parts and components, we simply use the share of FDI over that of GDP. To capture the impact of telecommunications, we 
use the number of telephone lines per 1,000 people to represent the index for telephone lines.

The data on trade in parts and components between China and its trading partners are taken from UNCTAD (2006), covering 219 products. The time period runs from 1992 to 2004 and the sample comprises 20 countries, as introduced in the last section. GDP for each country is taken from the Penn World Table 6.2. The indexes we have chosen are 'CGDP' and 'POP' and their products are used as the GDP variable. The data of FDI are taken from the China Statistical Yearbooks for 1993-2005 (NBS various issues). The data for economic distance are taken from Haveman (2004). The data of telephone lines per 1,000 people are taken from the World Development Indicators (World Bank 2006). The data of average labour unit costs per hour are taken from EIU Country Data (Economist Intelligence Unit 2007).

The empirical results are reported in Tables 5 and 6, showing the determinants of China's imports and exports of parts and components respectively. In each table, there are two groups of results: one contains no variable of LNTELELINE and the other contains this variable. Both results show good fitness of our model specification, since the R-squares for the two model estimations are 0.7 and 0.8 respectively.

The results show that the coefficients of $L N A G D P$ in all regressions are positive and statistically significant at the 1 per cent level, implying that China's size and economies of scale and its trading partners has a positive impact on China's imports of parts and components. That is, the larger the economies of scale, the greater trade in parts and components will be. Furthermore, comparing this result with that from the regression using Equation 2, we found that the impact of economies of scale on trade in parts and components was larger than that of final goods. This is consistent with findings obtained in Jones and Kierzkowski (2005).

The coefficients of LNDIST - as the measurement of the impact of transport and other costs on bilateral trade flows - are negative and statistically significant, as expected. Despite the fact that the rapid development of telecommunications techniques leads to the 'death of distance' (Cairncross 1997), the estimated coefficient of economic distance is still negative and statistically significant. This implies that trade in parts and components in China relative to its trading partners is still sensitive to the changes in transportation costs and the physical distance between them.

As expected, FDI has a positive impact on China's imports and exports of parts and components and it is statistically significant at the 1 per cent level. The regression results show that the impact of FDI on exports of parts and components is similar to that of imports and the magnitudes of the estimated coefficient are within the range of $0.2-$ 0.3. This finding implies that a 1 per cent increase in FDI could lead to a $0.2-0.3$ per cent increase in China's exports of parts and components. The purpose of FDI is twofold: one is to sell products to China's domestic market and the other is to make use of China's comparative advantage of low-cost labour. Both motives could lead to increased trade in parts and components.

Tables 5 and 6 also show the results when LNTELELINE is incorporated as the measurement to capture the impact of telecommunications on component trade. As is expected, the telecommunications service and its coverage have a significant positive impact on international specialization through trade in parts and components. 
The results of LNRWAGE show significant differences between the regressions of imports of parts and components, which is consistent with what the theory of comparative advantage would predict. For China's imports of parts and components, The coefficients of foreign countries' labour costs are positive and statistically significant at the 5 per cent level (Table 5). The results imply that the relatively low cost of labour in China is one of the most important determinants of the rapid development of trade in parts and components between China and its trading partners - since China's comparative advantage in labour costs attracts greater imports of parts and components for assembly.

The estimated results show, however, that there is no significant difference for the variable of LNRWAGE (Table 6) in determining China's exports of parts and components. The insensitivity of wage differentials in determining China's exports of parts and components remains a puzzle, which requires further study.

Since all the factors included in the regressions would have similar effects on trade in final products, we can also run the regression with the share of trade in parts and components in total manufacturing trade as the dependent variable in both equations, the estimation results are reported in Table 7. Comparison with the previous results shows that economies of scale have a significantly positive impact on trade in parts and components, while transportation costs have a significantly negative impact. The findings are consistent with those reported in Tables 5 and 6. Furthermore, the impact of FDI on exports in parts and components is not statistically significant compared with the results in Table 6.

The impact of labour costs is significantly negative in the export shares in total manufacturing exports, which is in contrast with the finding of positive correlation in China's imports of parts and component (Table 5). This suggests that the theory of comparative labour cost applies more to China's imports of parts and components than to its exports of them. Since China's imports of parts and components concentrate more on capital and technology intensive goods such as machinery and transportation (Table 1), the finding of positive correlation of labour cost differentials may suggest that foreign firms investing in China are more sensitive to labour cost differences between China and elsewhere in those more sophisticated parts and components. It is understandable as labour costs in producing these kinds of intermediate goods in developed countries are much higher than that in China (Table 4), whereas the labour cost differentials between industrialized and developing economies in producing less sophisticated intermediate goods tend to be narrower. Since China's exports of parts and components concentrate more on those less sophisticated labour intensive products, both foreign firms and domestic firms producing such intermediates goods tend to become less sensitive to labour cost differentials. Under this circumstance, market size, economies of scale and service links rather than FDI and labour cost differentials will play more important roles in determining the pattern of exports of parts and components. Finally, consistent with the findings reported in Tables 5 and 6, the development in telecommunications is also correlated positively with the shares of exports of parts and components in total manufacturing exports. 
The empirical results reveal the following points. First, China's rapid economic growth, increasing market size and economies of scale are important factors in explaining the rapid increase of bilateral trade in parts and components with its trading partners. Second, the spatial distance and transportation costs have significant negative impacts on China's trade of parts and components. This suggests that the reduction in transportation costs by technological innovation and investment could enhance trade in parts and components, and thereby deepen the process of international specialization involving China and its main trading partners. Third, FDI has a positive impact on China's participation in international fragmentation of production, taking advantage of China's comparative advantage in low labour costs in assembly of intermediate goods and producing final goods for domestic sales and exports. Finally, the development of the telecommunications and related services sector helps intensify the degree of international specialization by reducing transaction costs, which will encourage more domestic and foreign firms to be involved in international fragmentation of production.

Along with the trend of globalization, China has become an important player in the international production chain through its increasing share of trade in parts and components with its main trading partners. China has now been incorporated into the regional production network consisting of Korea, Japan, Hong Kong, Taiwan and six ASEAN countries and is engaged in trading relationships with North American and European economies for parts and components. China has achieved tremendous dynamic gains from engaging in trade in parts and components especially with respect to its industrial upgrading through technological learning associated with processing trade (Amighini 2004). For the East Asian economies, the accession of China into such a regional production network has not only encouraged the further development of regional trade liberalization including service trade liberalization, it has also provided an enlarged market for all the regional economies. As a result, all parties involved will gain from participating in this dynamic process. Given the prospects of the rapid growth of the Chinese economy, its current and planned massive investments in research and development and in infrastructure including transportation and telecommunications, its continual policies in attracting FDI and its rapid move towards liberalizing its services sectors, the scope for China and its trading partners to benefit from the process of international fragmentation of production is tremendous. 


\section{References}

Amighini, A. (2004). 'China in the International Fragmentation of Production: Evidence from the ICT Industry'. The European Journal of Comparative Economics, 2(2): 203-19.

Athukorala, P. C. (2006). 'Multinational Production Networks and the New GeoEconomic Division of Labour in the Pacific Rim'. Paper for the thirty-first Pacific Trade and Development Conference, Guadalajara, Mexico.

Cairncross, F. (1997). The Death of Distance. Boston: Harvard Business Press.

Cheng, L., L. D. Qiu, and G. Tan (2001). 'Foreign Direct Investment and International Fragmentation of Production', in S. Arndt, and H. Kierzkowski (eds), Fragmentation: New Production Patterns in the World Economy. New York: Oxford University Press: 165-86.

China Economic Information Network (2007). Available from http://www.cei.gov.cn

Economist Intelligence Unit (EIU) (2007). CountryData. Available from http://www.eiu.com

Egger, H., and P. Egger (2005). 'The Determinants of EU Processing Trade'. The World Economy, 28(2): 147-68.

Feenstra, R. (1998). 'Integration of Trade and Disintegration of Production in the Global Economy’. Journal of Economic Perspectives, 12(4): 31-50.

Gaulier, G., F. Lemoine, and D. Unal-Kesenci (2005). China's Integration in East Asia: Production Sharing, FDI and High-tech Trade. Working Paper 2005-09, CEPII.

Grossman, G. M., and E. Helpman (2003). 'Outsourcing vs FDI in Industry Equilibrium’, Journal of the European Economic Association, 1: 317-27.

Haveman, J. (2004). Industry Concordances. Available from http://www.macalester.edu/research/economics/PAGE/HAVEMAN/Trade.Resources /TradeConcordances.html\#gravity

Jones, R. W., and H. Kierzkowski (2001). 'A Framework for Fragmentation', in S. Arndt and H. Kierzkowski (eds), Fragmentation: New Production Patterns in the World Economy. Oxford University Press: Oxford: 17-34.

Jones, R. W., and H. Kierzkowski (2005). 'International Fragmentation and the New Economic Geography'. North American Journal of Economics and Finance, 16(1): $1-10$.

Jones, R. W., H. Kierzkowski, and L. Chen (2005). 'What Does Evidence Tell us About Fragmentation and Outsourcing?'. International Review of Economics and Finance, 14: 305-16.

Jones, R. W., and S. Marjit (2001). 'The Role of International Fragmentation in the Development Process'. American Economic Review, 91(2): 363-6.

Jones, R. W. (2007). 'Production Fragmentation and Outsourcing: General Concerns'. University of Rochester, unpublished article. 
Kaminski, B., and B. K. Smarzynska (2001). Foreign Direct Investment and Integration into Global Production and Distribution Networks: The Case of Poland. World Bank Policy Research Working Paper 2646, Washington, DC.

National Bureau of Statistics (NBS) (2006). China Statistical Yearbook. Beijing: China Statistical Press.

National Bureau of Statistics (NBS) (2006). Various Issues. China Statistical Yearbook. Beijing: China Statistical Press.

Penn World Tables (n.d.). Centre for International Comparisons at the University of Pennsylvania, Philadelphia.

Spencer, B. J. (2005). 'International Outsourcing and Incomplete Contracts'. National Bureau of Economic Research Working Paper 11418.

United Nations Conference on Trade and Development (UNCTAD) (2006). Trade and Development Report. New York and Geneva: United Nations.

Yeats, A. J. (2001). 'How Big is Global Production Sharing?', in S. Arndt and H. Kierzkowski (eds), Fragmentation: New Production Patterns in the World Economy. Oxford: Oxford University Press.

World Bank (2006). World Development Indicators. Washington, DC: World Bank. 
Table 1: China's trade in parts and components, 1992-2004

\begin{tabular}{|c|c|c|c|c|c|c|}
\hline & \multicolumn{3}{|c|}{ SITC-7 } & \multicolumn{3}{|c|}{ SITC-8 } \\
\hline & $\begin{array}{c}\text { Value } \\
\text { (US\$ billion) }\end{array}$ & $\begin{array}{l}\text { Share in } \\
\text { P\&C } \\
\text { (per cent) }\end{array}$ & $\begin{array}{c}\text { Share in } \\
\text { manufacturing } \\
\text { (per cent) }\end{array}$ & $\begin{array}{c}\text { Value } \\
\text { (US\$ billion) }\end{array}$ & $\begin{array}{l}\text { Share in } \\
\text { P\&C } \\
\text { (per cent) }\end{array}$ & $\begin{array}{c}\text { Share in } \\
\text { manufacturing } \\
\text { (per cent) }\end{array}$ \\
\hline \multicolumn{7}{|c|}{ Exports } \\
\hline 1992 & 3.4 & 80 & 5.1 & 0.8 & 19.1 & 1.2 \\
\hline 1996 & 10 & 87 & 7.8 & 1.5 & 13.2 & 1.2 \\
\hline 2000 & 28 & 92 & 12.4 & 2.4 & 8.0 & 1.1 \\
\hline 2004 & 87 & 94 & 15.9 & 5.5 & 5.8 & 1.0 \\
\hline \multicolumn{7}{|c|}{ Imports } \\
\hline 1992 & 10 & 87 & 15.8 & 1.6 & 13.1 & 2.4 \\
\hline 1996 & 20 & 92 & 17.7 & 1.7 & 8.1 & 1.1 \\
\hline 2000 & 51 & 96 & 29.1 & 2.1 & 4.0 & 1.2 \\
\hline 2004 & 148 & 97 & 33.4 & 4.1 & 2.7 & 1.0 \\
\hline
\end{tabular}

Note: SITC-7 denotes parts and components for machinery and transport equipment, and SITC8 represents miscellaneous manufacturing commodities.

Source: Authors' calculations based on United Nations Conference on Trade and Development (UNCTAD 2006). Trade and Development Report, United Nations, New York and Geneva. 
Table 2: Shares of component imports trade in China, by region, 1992-2005 (per cent)

\begin{tabular}{|c|c|c|c|c|c|c|c|c|}
\hline Region/country & 1992 & 1993 & 1996 & 1997 & 2000 & 2001 & 2004 & 2005 \\
\hline World & 100 & 100 & 100 & 100 & 100 & 100 & 100 & 100 \\
\hline NAFTA ${ }^{a}$ & 10.1 & 10.7 & 10.7 & 11.9 & 10.7 & 11.4 & 7.0 & 6.5 \\
\hline United States & 9.6 & 10.3 & 9.8 & 10.9 & 8.5 & 9.4 & 5.8 & 5.5 \\
\hline Canada & 0.6 & 0.4 & 0.9 & 0.9 & 1.6 & 1.2 & 0.5 & 0.4 \\
\hline Mexico & - & - & - & 0.1 & 0.6 & 0.8 & 0.6 & 0.6 \\
\hline EU (4) & 13.9 & 13.7 & 10.2 & 10.8 & 10.9 & 11.2 & 7.6 & 6.1 \\
\hline Germany & 8.2 & 8.7 & 6.4 & 6.3 & 5.7 & 6.4 & 5.2 & 3.7 \\
\hline France & 2.4 & 1.6 & 1.4 & 1.8 & 2.7 & 2.3 & 1.2 & 1.2 \\
\hline United Kingdom & 1.3 & 1.7 & 1.3 & 1.7 & 1.7 & 1.5 & 0.6 & 0.6 \\
\hline Italy & 2.1 & 1.6 & 1.2 & 0.9 & 0.9 & 0.9 & 0.6 & 0.5 \\
\hline Northeast Asia & 61.5 & 54.5 & 58.8 & 57.6 & 52.7 & 51.1 & 52.9 & 53.4 \\
\hline Hong Kong & 38.7 & 16.2 & 9.5 & 7.6 & 5.4 & 5.1 & 2.6 & 2.1 \\
\hline Japan & 20.2 & 32.1 & 35.1 & 32.3 & 25.9 & 24.2 & 20.8 & 17.9 \\
\hline Korea & 1.8 & 3.9 & 7.5 & 8.4 & 9.3 & 8.4 & 12.6 & 15.3 \\
\hline ASEAN (5) & 0.8 & 2.2 & 6.7 & 9.3 & 12.1 & 13.4 & 16.8 & 18.0 \\
\hline Indonesia & - & - & 0.1 & 0.2 & 0.4 & 0.5 & 0.5 & 0.4 \\
\hline Malaysia & 0.1 & 0.3 & 1.5 & 2.1 & 4.5 & 5.4 & 6.6 & 6.9 \\
\hline Philippines & - & - & 0.3 & 0.2 & 1.9 & 2.2 & 4.4 & 5.2 \\
\hline Singapore & 0.6 & 1.6 & 3.7 & 5.4 & 2.8 & 2.7 & 3.1 & 3.4 \\
\hline Thailand & 0.1 & 0.1 & 1.1 & 1.4 & 2.4 & 2.6 & 2.2 & 2.1 \\
\hline Australia & 0.1 & 0.2 & 0.2 & 0.2 & 0.1 & 0.1 & 0.1 & 0.1 \\
\hline Other & 14.2 & 20.9 & 19.3 & 19.4 & 25.3 & 25.8 & 32.1 & 33.7 \\
\hline
\end{tabular}

Note: ${ }^{a}$ North American Free Trade Agreement.

Source: Authors' calculations based on United Nations Conference on Trade and Development (UNCTAD 2006). Trade and Development Report, United Nations, New York and Geneva. 
Table 3: Share of exports of parts and components from China, by region, 1992-2005 (per cent)

\begin{tabular}{lrrrrrrrr}
\hline Region/country & 1992 & 1993 & 1996 & 1997 & 2000 & 2001 & 2004 & 2005 \\
\hline World & 100 & 100 & 100 & 100 & 100 & 100 & 100 & 100 \\
NAFTA & 7.2 & 17.2 & 16.0 & 16.0 & 16.1 & 16.6 & 17.2 & 17.2 \\
United States & 6.8 & 16.1 & 15.2 & 15.0 & 14.4 & 14.9 & 15.5 & 15.4 \\
Canada & 0.3 & 0.9 & 0.7 & 0.7 & 1.0 & 0.7 & 0.6 & 0.7 \\
Mexico & 0.1 & 0.2 & 0.1 & 0.3 & 0.6 & 1.0 & 1.0 & 1.0 \\
EU (4) & 2.2 & 9.1 & 5.8 & 6.2 & 7.4 & 6.6 & 7.1 & 7.1 \\
Germany & 1.0 & 4.6 & 2.6 & 2.6 & 3.1 & 2.6 & 3.2 & 3.7 \\
France & 0.3 & 1.8 & 0.9 & 1.1 & 1.2 & 0.9 & 1.1 & 0.9 \\
United Kingdom & 0.7 & 2.1 & 1.7 & 1.9 & 2.3 & 2.2 & 2.0 & 1.9 \\
Italy & 0.2 & 0.7 & 0.6 & 0.5 & 0.8 & 0.8 & 0.7 & 0.7 \\
Northeast Asia & 77.1 & 56.7 & 63.6 & 62.5 & 59.5 & 59.6 & 57.4 & 55.7 \\
Hong Kong & 62.3 & 30.1 & 26.7 & 26.4 & 26.6 & 27.0 & 28.0 & 28.4 \\
Japan & 9.1 & 17.4 & 20.5 & 19.6 & 15.4 & 15.0 & 11.7 & 10.5 \\
Korea & 1.2 & 2.4 & 5.5 & 4.9 & 4.8 & 4.6 & 5.3 & 4.9 \\
ASEAN (5) & 4.1 & 6.4 & 10.7 & 11.2 & 12.4 & 12.7 & 12.3 & 11.8 \\
Indonesia & 0.6 & 1.2 & 1.4 & 1.6 & 1.1 & 1.1 & 0.9 & 0.9 \\
Malaysia & 0.8 & 1.2 & 2.3 & 2.2 & 2.0 & 3.4 & 3.3 & 3.2 \\
Philippines & 0.3 & 0.3 & 0.7 & 1.3 & 1.3 & 0.7 & 1.4 & 1.2 \\
Singapore & 1.9 & 2.6 & 5.1 & 4.9 & 5.7 & 5.1 & 4.8 & 4.8 \\
Thailand & 0.5 & 0.8 & 0.8 & 1.0 & 2.0 & 2.1 & 1.4 & 1.4 \\
Australia & 0.2 & 0.3 & 0.4 & 0.4 & 0.5 & 0.5 & 0.5 & 0.5 \\
Other & 14.2 & 20.9 & 19.3 & 19.4 & 25.3 & 25.8 & 32.1 & 33.7 \\
\hline
\end{tabular}

Source: Authors' calculations based on United Nations Conference on Trade and Development (UNCTAD 2006). Trade and Development Report, United Nations, New York and Geneva. 
Table 4: Unit labour costs across different countries, 1992-2004 (US\$ of unit labour per hour)

\begin{tabular}{|c|c|c|c|c|c|c|c|c|c|c|c|c|c|}
\hline Country & 1992 & 1993 & 1994 & 1995 & 1996 & 1997 & 1998 & 1999 & 2000 & 2001 & 2002 & 2003 & 2004 \\
\hline United States & 16.0 & 16.4 & 16.8 & 17.2 & 17.8 & 18.2 & 18.6 & 18.9 & 19.7 & 20.6 & 21.4 & 22.3 & 22.9 \\
\hline Canada & 17.6 & 16.9 & 16.3 & 16.5 & 17.0 & 16.8 & 15.9 & 16.1 & 16.5 & 16.2 & 16.7 & 19.4 & 21.4 \\
\hline Mexico &.. &.. & .. & 1.1 & 1.0 & 1.1 & 1.2 & 1.3 & 1.6 & 1.9 & 1.9 & 1.9 & 1.9 \\
\hline Germany & 25.2 & 23.9 & 25.3 & 30.1 & 29.6 & 26.0 & 25.2 & 24.6 & 22.7 & 22.5 & 24.2 & 29.6 & 32.5 \\
\hline France & 17.3 & 16.5 & 17.1 & 19.3 & 19.0 & 17.1 & 17.3 & 17.0 & 15.5 & 15.6 & 17.1 & 21.1 & 23.9 \\
\hline United Kingdom & 14.3 & 12.5 & 13.0 & 13.8 & 14.1 & 15.7 & 17.0 & 17.3 & 16.7 & 16.7 & 18.2 & 21.2 & 24.7 \\
\hline Italy & 18.9 & 15.4 & 15.4 & 15.7 & 17.1 & 16.1 & 15.8 & 15.5 & 13.8 & 13.6 & 14.7 & 18.1 & 20.5 \\
\hline Australia & 13.2 & 12.6 & 14.1 & 15.4 & 17.0 & 16.7 & 15.1 & 15.9 & 14.4 & 13.3 & 15.4 & 19.8 & 23.1 \\
\hline Japan & 16.2 & 18.9 & 21.0 & 23.6 & 20.5 & 19.1 & 17.7 & 20.5 & 22.0 & 19.4 & 18.6 & 20.3 & 21.9 \\
\hline Korea & 5.2 & 5.6 & 6.4 & 7.3 & 8.2 & 7.8 & 5.7 & 7.4 & 8.2 & 7.7 & 8.8 & 10.0 & 11.5 \\
\hline Hong Kong & 3.9 & 4.3 & 4.6 & 4.8 & 5.1 & 5.4 & 5.4 & 5.4 & 5.4 & 5.7 & 5.7 & 5.5 & 5.5 \\
\hline Singapore & 4.9 & 5.2 & 6.2 & 7.6 & 8.2 & 8.0 & 7.4 & 7.0 & 7.2 & 7.0 & 6.7 & 7.2 & 7.4 \\
\hline Philippines & 0.6 & 0.7 & 0.7 & 0.8 & 0.8 & 0.8 & 0.7 & 0.7 & 0.7 & 0.7 & 0.7 & 0.7 & 0.7 \\
\hline Indonesia & 0.3 & 0.3 & 0.4 & 0.4 & 0.5 & 0.4 & 0.1 & 0.2 & 0.3 & 0.3 & 0.4 & 0.5 & 0.5 \\
\hline Thailand & 1.2 & 1.3 & 1.2 & 1.4 & 1.5 & 1.3 & 1.1 & 1.2 & 1.1 & 1.0 & 1.1 & 1.1 & 1.2 \\
\hline Malaysia & 1.9 & 2.0 & 2.2 & 2.5 & 2.7 & 2.6 & 1.9 & 2.0 & 2.1 & 2.1 & 2.2 & 2.2 & 2.2 \\
\hline Brazil & n.a. & n.a. & n.a. & n.a. & 5.8 & 5.8 & 5.6 & 3.5 & 3.6 & 3.0 & 2.7 & 2.8 & 3.4 \\
\hline India & 0.5 & 0.4 & 0.5 & 0.5 & 0.5 & 0.5 & 0.5 & 0.6 & 0.6 & 0.6 & 0.7 & 0.8 & 0.9 \\
\hline China & 0.2 & 0.3 & 0.3 & 0.3 & 0.4 & 0.5 & 0.5 & 0.5 & 0.6 & 0.7 & 0.8 & 0.9 & 1.0 \\
\hline
\end{tabular}

Source: Economist Intelligence Unit (EIU). 
Table 5: Estimation results of equation 1: imports

\section{LNIMPORT}

\begin{tabular}{|c|c|c|c|c|}
\hline \multirow{2}{*}{$\begin{array}{l}\text { Variable } \\
\text { C }\end{array}$} & \multicolumn{2}{|c|}{ (1) } & \multicolumn{2}{|c|}{ (2) } \\
\hline & $-83.84^{\star \star \star}$ & $-57.32^{\star \star \star}$ & $-85.10^{\star \star *}$ & $-43.69^{\star \star \star}$ \\
\hline & $(-14.27)$ & $(-12.51)$ & $(-15.45)$ & $(-5.72)$ \\
\hline \multirow[t]{2}{*}{ LNAGDP } & $4.83^{\star \star *}$ & $3.53^{* * *}$ & $4.70^{* * *}$ & $2.76^{\star * *}$ \\
\hline & (16.42) & (15.51) & (16.31) & (6.59) \\
\hline \multirow[t]{2}{*}{ LNDIST } & $-0.96^{\star * *}$ & $-0.74^{\star * *}$ & $-0.90^{\star \star \star}$ & $-0.58^{\star \star \star}$ \\
\hline & $(-11.75)$ & $(-11.12)$ & $(-10.69)$ & $(-5.84)$ \\
\hline \multirow[t]{2}{*}{ LNFDI } & $0.19^{\star \star \star}$ & $0.26^{\star \star *}$ & $0.16^{\star \star *}$ & $0.28^{\star * \star}$ \\
\hline & (3.85) & 6.60 & (3.43) & $(7.16)$ \\
\hline \multirow[t]{2}{*}{ LNRWAGE } & $0.71^{\star \star *}$ & $0.64^{\star \star \star}$ & $0.31^{* *}$ & $0.32^{\star \star}$ \\
\hline & (5.39) & 4.98 & (2.36) & $(2.17)$ \\
\hline \multirow[t]{2}{*}{ LNTELELINE } & & & $0.99^{* * *}$ & $0.55^{\star}$ \\
\hline & & & (3.88) & $(2.40)$ \\
\hline Fixed effect & Yes & No & Yes & No \\
\hline Adjusted $\mathrm{R}^{2}$ & 0.74 & 0.73 & 0.76 & 0.74 \\
\hline SE & 1.14 & 1.13 & 1.10 & 1.12 \\
\hline F-statistic & 36.73 & 147.32 & 38.15 & 122.31 \\
\hline $\begin{array}{l}\text { Number of } \\
\text { observations }\end{array}$ & 221 & 221 & 221 & 221 \\
\hline
\end{tabular}

Note: ${ }^{* *} 1$ per cent significant level, ${ }^{* *} 5$ per cent significant level, * 10 per cent significant level. T-statistics are in parentheses.

Source: Authors' calculations. 
Table 6: Estimation results of equation 1: exports

\section{LNEXPORT}

\begin{tabular}{|c|c|c|c|c|}
\hline \multirow{2}{*}{$\begin{array}{l}\text { Variable } \\
\text { C }\end{array}$} & \multicolumn{2}{|c|}{ (1) } & \multicolumn{2}{|c|}{$(2)$} \\
\hline & $-70.70^{\star * \star}$ & $-47.49^{\star * \star}$ & $-71.42^{\star * \star}$ & $-41.76^{\star * *}$ \\
\hline & $(-9.79)$ & $(-15.42)$ & $(-8.54)$ & $(-7.45)$ \\
\hline \multirow[t]{2}{*}{ LNAGDP } & $4.19^{\star \star \star}$ & $3.05^{\star * *}$ & $4.12^{\star * *}$ & $2.73^{\star * *}$ \\
\hline & $(11.37)$ & (18.54) & $(9.63)$ & $(8.71)$ \\
\hline \multirow[t]{2}{*}{ LNDIST } & $-0.68^{\star \star \star}$ & $-0.48^{\star \star \star}$ & $-0.65^{\star \star \star}$ & $-0.41^{\star \star \star}$ \\
\hline & $(-8.08)$ & $(-9.65)$ & $(-6.90)$ & $(-5.29)$ \\
\hline \multirow[t]{2}{*}{ LNFDI } & $0.24^{\star \star \star}$ & $0.30^{\star \star \star}$ & $0.22^{\star \star *}$ & $0.31^{* \star *}$ \\
\hline & $(4.32)$ & (7.19) & (3.72) & $(6.66)$ \\
\hline \multirow[t]{2}{*}{ LNRWAGE } & 0.13 & 0.05 & $-0.16^{*}$ & -0.09 \\
\hline & (1.63) & $(0.89)$ & $(-1.71)$ & $(-0.78)$ \\
\hline \multirow[t]{2}{*}{ LNTELELINE } & & & $0.56^{\star \star \star}$ & $0.23^{*}$ \\
\hline & & & $(7.56)$ & $(1.72)$ \\
\hline Fixed effect & Yes & No & Yes & No \\
\hline Adjusted $\mathrm{R}^{2}$ & 0.86 & 0.85 & 0.87 & 0.85 \\
\hline SE & 0.64 & 0.65 & 0.62 & 0.65 \\
\hline F-statistic & 81.32 & 311.78 & 83.35 & 253.01 \\
\hline Number of observations & 221 & 221 & 221 & 221 \\
\hline
\end{tabular}

Notes: ${ }^{* \star *} 1$ per cent significant level, ${ }^{* *} 5$ per cent significant level, ${ }^{*} 10$ per cent significant level. T-statistics are in parentheses.

Source: Authors' calculations. 
Table 7: Estimation results of equation 2: export shares in total manufacturing exports

\begin{tabular}{|c|c|c|c|c|}
\hline \multirow{3}{*}{$\begin{array}{l}\text { Variable } \\
\text { C }\end{array}$} & \multicolumn{4}{|c|}{ LNSEXPORT } \\
\hline & \multicolumn{2}{|c|}{ (1) } & \multicolumn{2}{|c|}{ (2) } \\
\hline & $-19.37^{* \star *}$ & $-19.00^{\star \star \star}$ & $-19.46^{\star \star \star}$ & $-17.14^{\star \star \star}$ \\
\hline & $(-5.97)$ & $(-10.30)$ & $(-6.16)$ & $(-9.88)$ \\
\hline \multirow[t]{2}{*}{ LNAGDP } & $1.09^{\star \star \star}$ & $1.07^{\star \star *}$ & $1.09^{* * *}$ & $0.97^{\star * \star}$ \\
\hline & $(6.87)$ & $(11.93)$ & $(7.06)$ & (11.33) \\
\hline \multirow[t]{2}{*}{ LNDIST } & $-0.34^{* * *}$ & $-0.33^{\star * *}$ & $-0.34^{\star \star \star}$ & $-0.31^{\star \star \star}$ \\
\hline & $(-12.25)$ & $(-16.43)$ & $(-12.94)$ & $(-16.76)$ \\
\hline \multirow[t]{2}{*}{ LNFDI } & -0.02 & -0.01 & -0.02 & 0.00 \\
\hline & $(-1.04)$ & $(-0.54)$ & $(-1.15)$ & $(-0.33)$ \\
\hline \multirow[t]{2}{*}{ LNRWAGE } & $-0.12^{\star * *}$ & $-0.14^{\star * *}$ & $-0.15^{\star \star *}$ & $-0.18^{\star * \star}$ \\
\hline & $(-4.46)$ & $(-5.11)$ & $(-6.24)$ & $(-5.85)$ \\
\hline \multirow[t]{2}{*}{ LNTELELINE } & & & $0.07^{\star}$ & $0.08^{\star *}$ \\
\hline & & & $(1.77)$ & $(2.54)$ \\
\hline Fixed effect & Yes & No & Yes & No \\
\hline Adjusted $\mathrm{R}^{2}$ & 0.70 & 0.67 & 0.70 & 0.67 \\
\hline S.E. & 0.39 & 0.40 & 0.40 & 0.40 \\
\hline F-statistic & 29.44 & 110.79 & 27.69 & 88.81 \\
\hline Number of observations & 221 & 221 & 221 & 221 \\
\hline
\end{tabular}

Note: ${ }^{* * *} 1$ per cent significant level, ${ }^{* *} 5$ per cent significant level, ${ }^{*} 10$ per cent significant level, T-statistic in parentheses.

Source: Authors' estimation. 
Figure 1: China's imports and exports of parts and component: 1992-2005 (billion US\$)

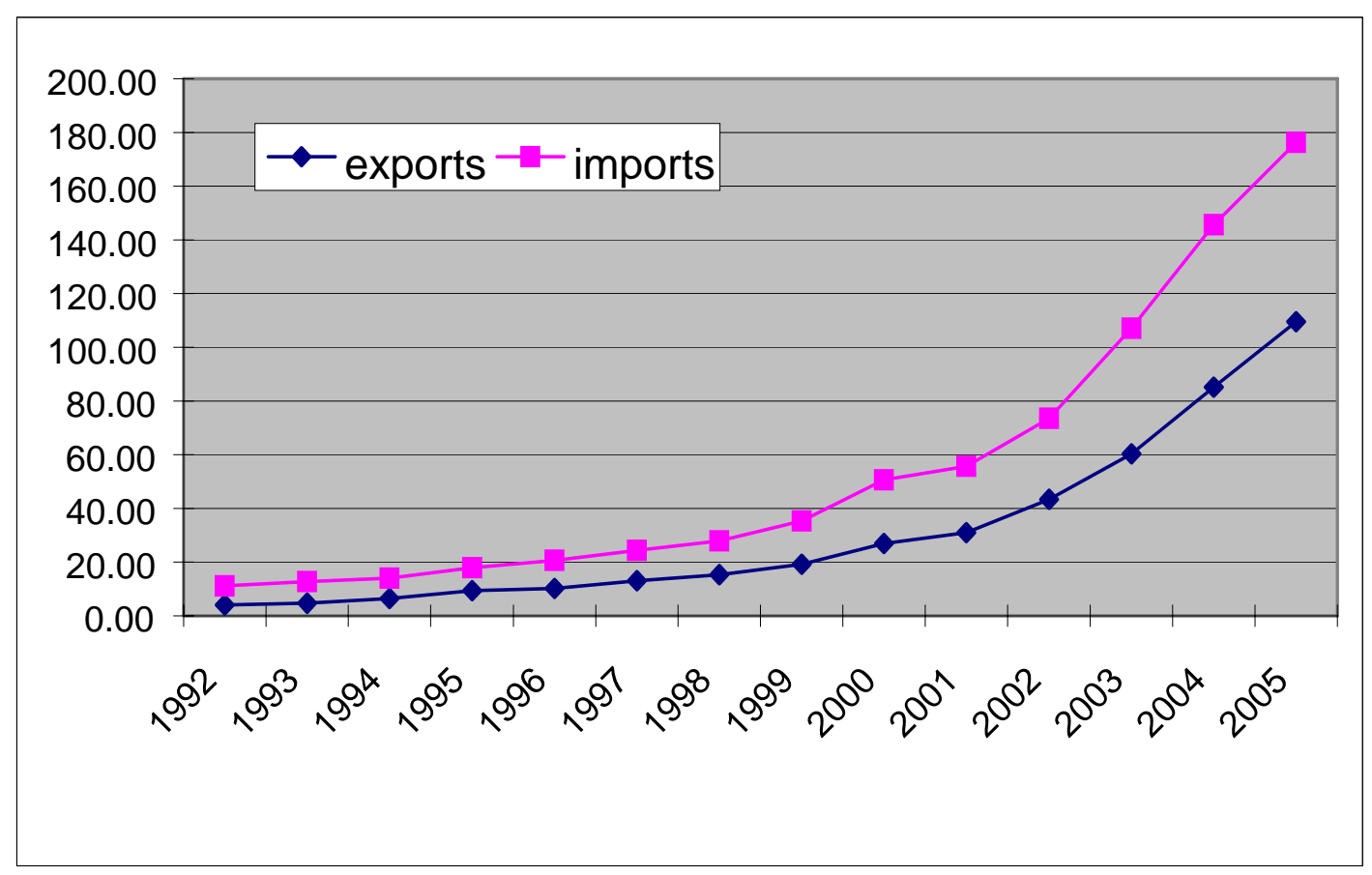

Source: Calculated using the data from UN COMTRADE (2006).

Figure 2: Share of parts and components trade in manufacturing trade: 1992-2005 (\%)

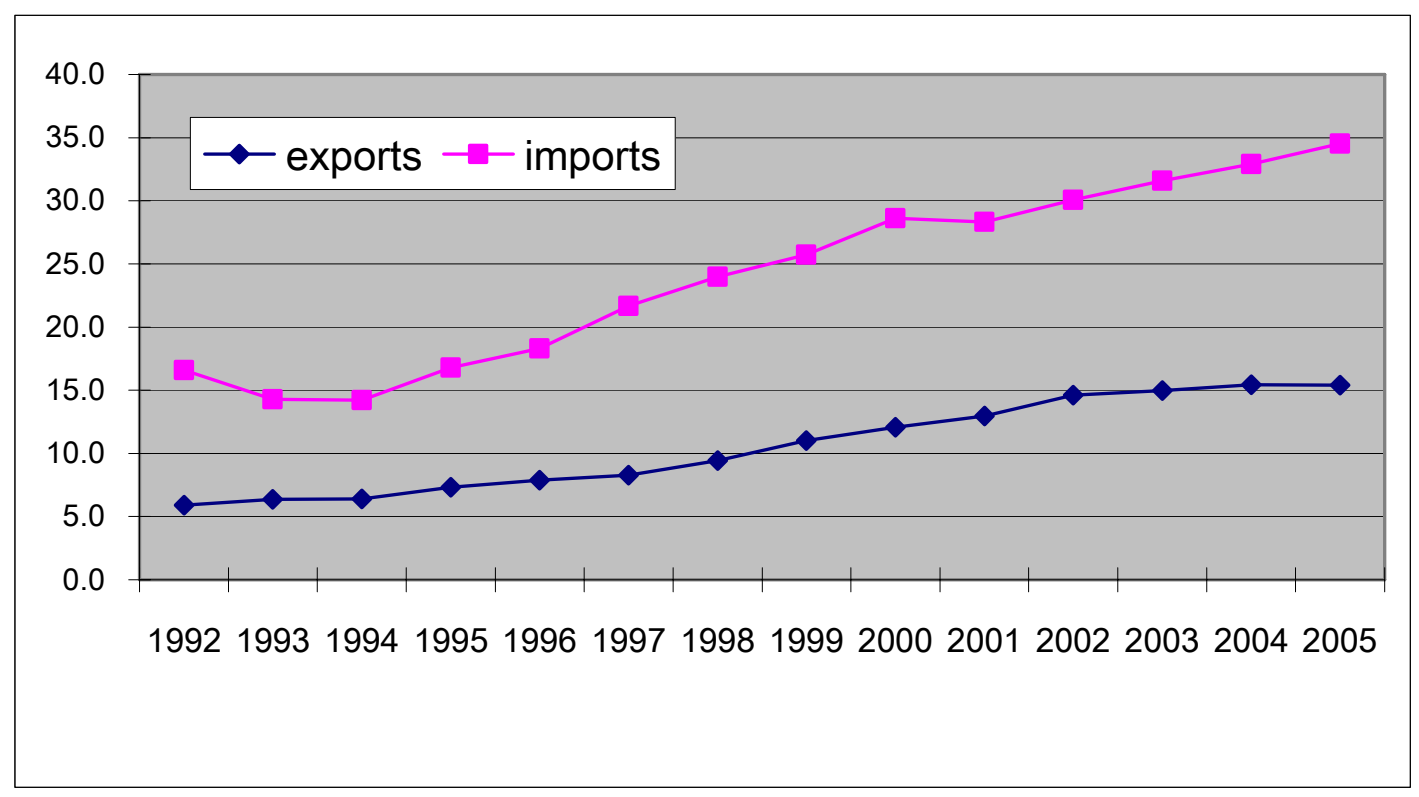

Source: Calculated using the data from UN COMTRADE (2006). 
Figure 3: Number of civil aviation airline routes in China, 1986-2005

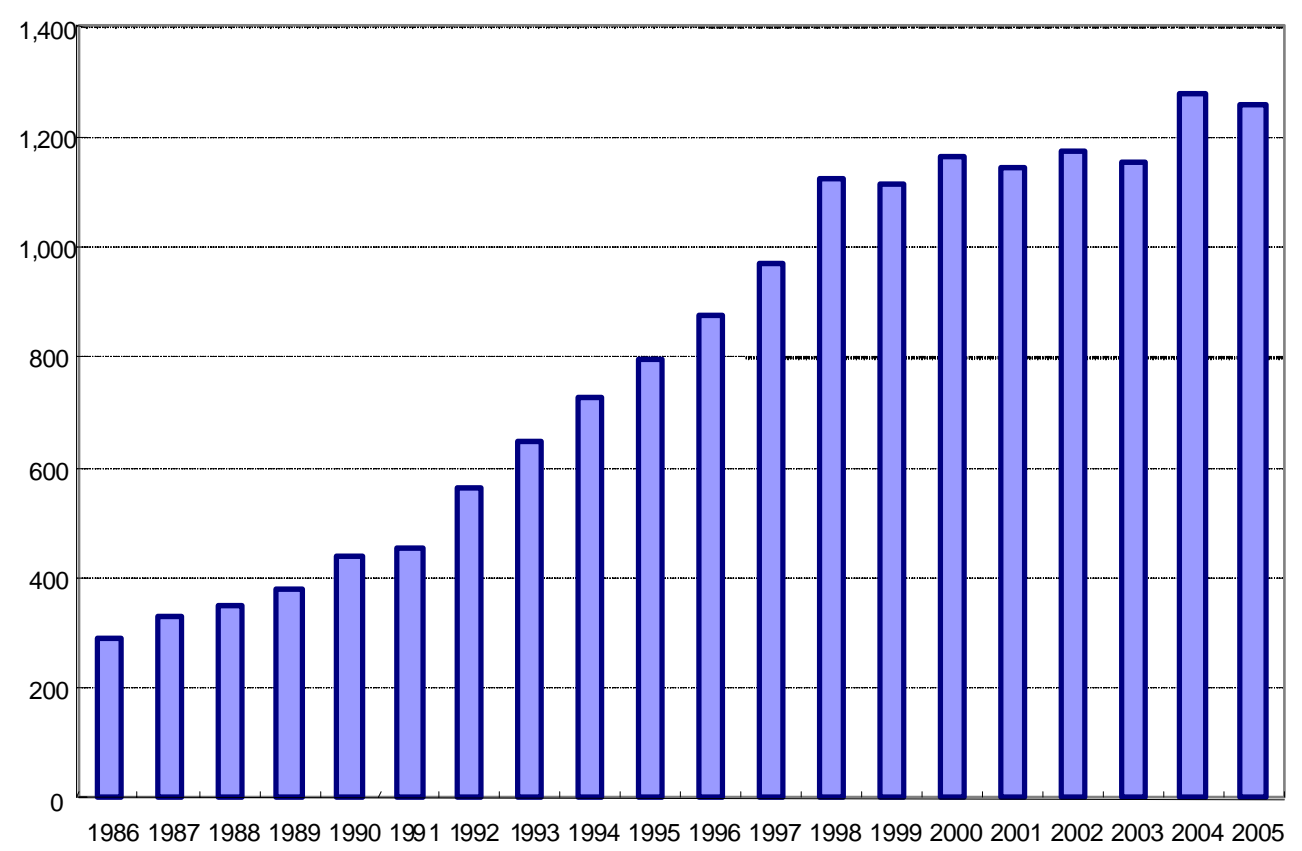

Source: Data from China Economic Information Network. Available from http://www.cei.gov.cn.

Figure 4: Scale of seaport trade in China, 1985-2005 (10,000 tonnes)

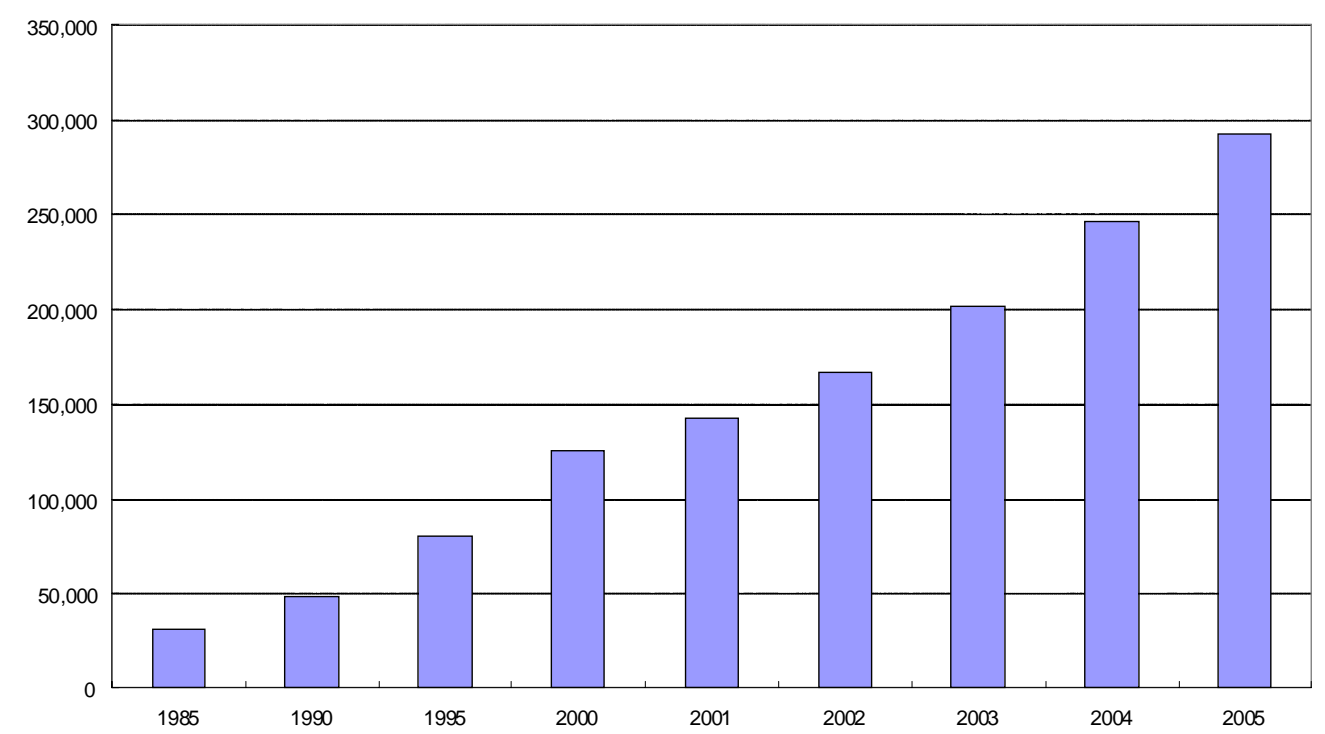

Source: Data from National Bureau of Statistics (NBS) (2006). China Statistical Yearbook, China Statistical Press, Beijing. 
Figure 5: Number of telephones per 1,000 people in China

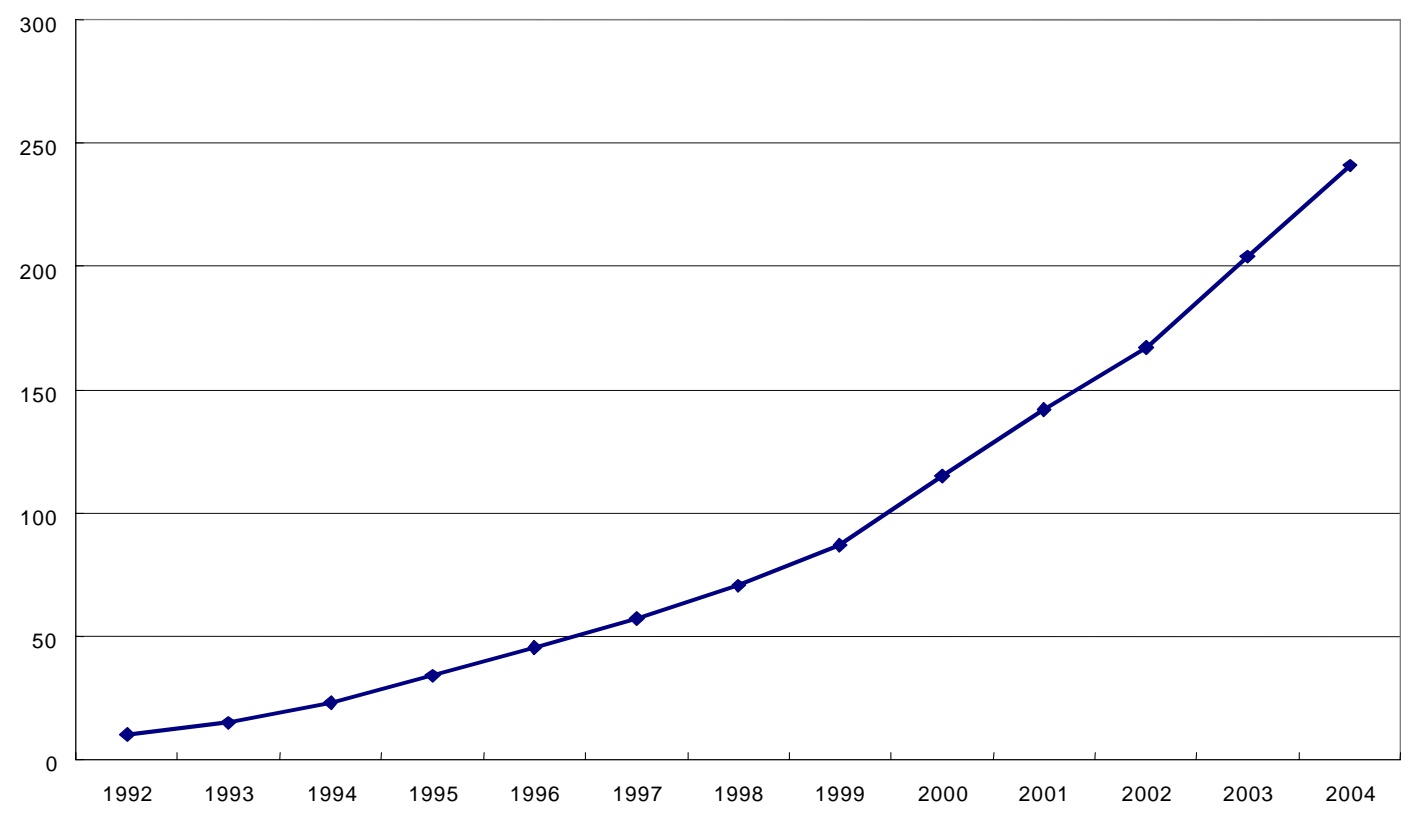

Source: Data from World Bank (2006). World Development Indicators, World Bank, Washington, DC.

Figure 6: China's utilized FDI (US\$100 million)

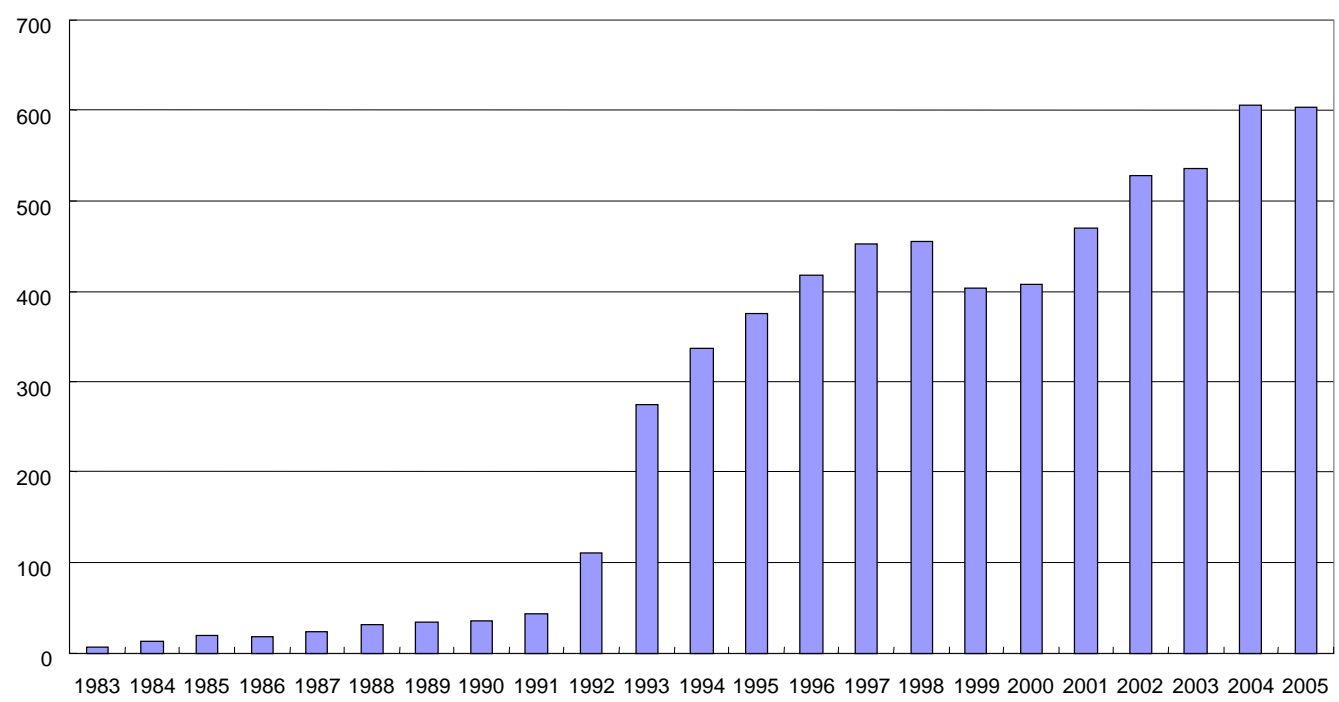

Source: Data from China Economic Information Network. Available from http://www.cei.gov.cn. 